\title{
ANALYSIS OF RECORDING, CALCULATION AND REPORTING OF VALUE ADDED TAX (VAT) BASED ON E-FAKTUR AT PT. BERKAT REHOBOT MANADO
}

\author{
Riri I. C Lumikis ${ }^{1}$, Ventje Ilat ${ }^{2}$ \\ ${ }^{1,2}$ Pendidikan Profesi Akuntansi, Fakultas Ekonomi dan Bisnis, Universitas Sam Ratulangi, J1. Kampus Bahu, \\ Manado, 95115, Indonesia \\ email : riri.lumikis@yahoo.co.id
}

\begin{abstract}
Value Added Tax (VAT) is a tax imposed at the time the company makes a purchase on Taxable Goods (BKP) / Taxable Services (JKP) charged from the Tax Imposition Basis (DPP). Every purchase of goods to be produced/sold, then the tax imposed on the goods, by Taxable Enterpreneurs (PKP) is a Tax Enter 10\% of the sale price before tax as Value Added Tax (VAT) which is the output tax for the tax period concerned. The type of data used in this study is, Qualitative Data is data obtained from data collection techniques through interviews, analysis of focused discussion documents or observations recorded in the report. This research was conducted at PT. Berkat Rehobot. Research conducted on the recording, calculation and reporting of Value Added Tax (VAT) at PT. Berkat Rehobot it can be concluded that this company has done accounting of Value Added Tax (VAT) in accordance with Law Number 42 Year 2009. As for the calculation and reporting using e-Faktur application so that the lack of errors that occur. If there is a lack of delays or correction in reporting due to delays in the delivery of existing Input Tax Invoice. However, the overall calculation and reporting has been in accordance with the Director General of Tax Regulation No. PER-16 / PJ / 2014.
\end{abstract}

Keywords: VAT Recording, Counting and Reporting

\section{INTRODUCTION}

In order to achieve the National Development Goals, the Government intensively conducts various strategic policies related to both short-term development programs and long-term development programs. And for the success of the national development program is certainly required development funds are not small. Therefore, the government seeks to increase state revenues, especially from the taxation sector, of course, by taking into account the capabilities of the community and the business world. Taxation sector is the biggest financial source in executing the government and development, even State revenue in this sector always increase from year to year. The role of taxes as a source of state revenue is now greater, if government revenue intends to reduce dependence on foreign loans. Tax revenues are increasingly becoming a cornerstone as population and welfare increases. While the other main source of revenue of the State, namely oil and gas, unreliable price stability and tend to decline its acceptance in line with the limited amount of natural resources.

Value Added Tax (VAT) is a tax imposed at the time the company makes a purchase on Taxable Goods (BKP) / Taxable Services (JKP) charged from the Tax Imposition Basis (DPP). Every purchase of goods to be produced / sold, then the tax imposed on the goods, by Taxable Enterpreneurs (PKP) is a Tax Enter 10\% of the sale price before tax as Value Added Tax (VAT) which is the output tax for the tax period concerned. Value Added Tax (VAT) is collected when we issue the tax invoice along with the invoice. The date indicated on the invoice must be in accordance with the date of the tax invoice, and all issued invoices must be paid VAT by the end of the month in accordance with law. If the company delays the 
reporting of Value Added Tax (VAT) to the State, pursuant to Article 7 of the KUP Law No.28 of 2007 shall be subject to a fine of Rp 500,000, and each month shall be subject to a fine of $2 \%$ of the total tax the deposited. To help PT. Berkat Rehobot in recording, calculation and reporting of Value Added Tax (VAT) based on e-Faktur in order to avoid mistake then conducted a research entitled "Analysis of Recording, Calculation and Reporting Value Added Tax (VAT) e-Faktur At PT. Berkat Rehobot Manado ".

\subsection{Problem Formulation}

1. How is the recording, calculation and reporting of Value Added Tax (VAT) based on e-Faktur of PT. Berkat Rehobot?

2. What is PT. Berkat Rehobot has implemented Value Added Tax (VAT) in accordance with Law No.42 Year 2009?

\subsection{Research Objectives}

1. To know the reporting of Value Added Tax (VAT) based e-Faktur in PT. Berkat Rehobot.

2. To determine whether the recording and calculation of Value Added Tax (VAT) has been in accordance with Law No.42 of 2009.

\section{LITERATURE REVIEWS}

\subsection{Concept of Accounting}

According to Charlles T. Horngren and Walter T. Harrison (Horngren Harrison, 2007:

4) understanding of accounting is an information system that is able to measure business activities, process data into reports, and communicate the results to the decision makers (Manager).

\subsection{The Accounting Treatment of Value Added Tax (VAT)}

According to Muljono (2009: 37) prior to recording the various collection or redemption of VAT, first need to specify the account number that will be used to accommodate various transactions related to the VAT, VAT recording can be distinguished to be as follows:

1. Recording VAT Debts

VAT debts occur when a Tax Payer sells BKP or JKP, so at a price that must be paid by the buyer of VAT to be collected by the Taxpayer. VAT debts for Taxpayers equals the output tax. The transaction journal of VAT debt can occur as follows:

Accounts Receivable $\quad$ xxx DPP Sales $\quad \mathrm{xxx}$

VAT Debt $\quad \mathrm{xxx}$

2. Recording of VAT Receivables

VAT receivables occur when the Tax Payer buys BKP or JKP so that at the price to be paid to the VAT to be paid by the Taxpayer. VAT receivables for Taxpayers equal to Input Tax. The transaction journal of VAT receivables may occur as follows:

DPP Purchase $\quad \mathrm{xxx}$

VAT receivables $\quad \mathrm{xxx}$

Accounts Payable $\quad x x x$

\subsection{VAT Calculation Should Be Paid}

According to Muljono VAT to be paid by the Taxpayer can be divided into:

1. Treated Calculation First

VAT payments by Taxpayers are made after the calculation of VAT and VAT receivables. The VAT to be paid by a Taxpayer or Taxable Entrepreneur is calculated on a monthly basis by adding up some of the tax debt owned, or equal to the Output Tax, and adding up all the VAT receivables owned, or equal to the Output Tax, and adding up all the VAT receivables owned, or equal to Input Tax. The difference 
between the VAT and VAT receivables is what the Taxpayer will pay. If the debt between VAT and VAT Receivables is greater then the receipt will be compensation or restitution.

2. Not Being Treated

The VAT to be paid by the Taxpayer on self-building is done without the computation of VAT and other VAT receivables. Regardless of the amount of VAT build on your own payable by the Taxpayer must be paid.

\subsection{Presentation and Reporting of VAT}

Presentation of VAT reports conducted every month by PKP is differentiated in accordance with the way the calculation of VAT to be paid, which is as follows:

1. Presentation of VAT Report for PKP Which Counts with Input Tax Output Tax (PKPM)

2. Presentation of VAT Report for PKP Which Calculation Not With Input Tax Output Tax (PKPM)

\subsection{Tax Concept}

Definition or understanding of tax according to Prof. Dr. Rochmat Soemitro, SH in Mardiasmo (2009: 1) Tax is a contribution of the people to state coffers by law (which can be enforced) with no direct (demonstrable) lead services to pay for public expenditures.

\subsection{Value Added Tax (VAT)}

Indirect Substraction Method is a method of calculating Value Added Tax (VAT) to be deposited to the State treasury by deducting tax on the acquisition with tax on the delivery of goods and services. Indonesia's Value Added Tax Act (PPN) adopts the Indirect Substraction Method.

In Article 1 Sub-Article 7 of the KUP Law, the Tax Period is the period of time which becomes the basis for taxpayers to calculate, deposit and report tax payable within a certain period of time as stipulated in Law (UU KUP).

Input Tax is Value Added Tax which should have been paid by Taxable Entrepreneur because of the acquisition of BKP and / or acceptance of JKP and / or utilization of BKP does not materialize from outside of Customs Area and or utilization of JKP from outside Customs Area and or utilization of JKP from outside Customs Area and or import BKP. Output tax is the payable VAT which must be collected by Taxable Person for VAT purposes, delivery of $\mathrm{BKP}$, delivery of JKP, or export of BKP.

Value added tax object is subject to:

1. Submission of BKP within the Customs Area conducted by Taxable Person for VAT purposes.

2. Import BKP

3. Submission of JKP conducted within the Customs Area by Taxable Enterpreneur.

4. Utilization of non-tangible BKP from outside the Customs Area;

5. Utilization of JKP from outside the Customs Area within the Customs Area;

6. Export of BKP by Taxable Entrepreneur;

To calculate the amount of tax (VAT and PPnBM) that owed the need for the Basic Tax Imposition (DPP). The DPP is; Selling price, Import Value, Export Value, and Other values stipulated by Decree of the Minister of Finance.

The current value is $10 \%$ (ten percent). How to calculate VAT is as follows:

\section{VAT $=$ Tax Imposition $\times$ Tax Tariff}

A Tax Invoice is a proof of tax levy made by a Taxable Person for VAT purposes that submits a BKP or surrender of JKP, or evidence of tax levy due to import of BKP used by the Directorate General of Customs and Excise. Tax Invoice can be: 
1. Standard Tax Invoice is a tax invoice made by Taxable Enterpreneurs (PKP) with reference to the provisions of the Directorate General of Taxes No.Kep-53 / PJ / 1994 valid since 29 December 994, and is obliged to be implemented as of January 1, 1995.

2. A Combined Tax Invoice is to alleviate the administrative burden, to a Taxable Enterpreneur allowed to make a Tax Invoice which includes all submissions of BKP or JKP deliveries occurring during one calendar month to the same buyer or the same JKP recipient.

3. Simple Tax Invoice is proof of tax levy made by Taxable Entrepreneur to accommodate the activities of BKP handover or JKP handover done directly to the final consumer.

Value Added Tax (VAT) is a tax on the consumption of goods and services in customs areas which are imposed on a graded basis in each production and distribution line. Example of calculating Value Added Tax (VAT);

A Taxable Person for VAT purposes sells Cash for Taxable Goods at a Selling Price of Rp $25,000,000$

Value Added Tax payable $=10 \% \times \operatorname{Rp} 25,000,000,-=\operatorname{Rp} 2,500,000,-$

Value Added Tax amounting to Rp 2.500.000, - is an Output Tax levied by Taxable Person for VAT purposes.

2.7 Regulation of the Director General of Taxation No. Per-16 / PJ / 2014 About the Procedure for Making and Reporting Electronic Tax Invoices

An electronic tax invoice, hereinafter called e-Invoice, is a tax invoice created through an application or electronic system specified and / or provided by the Directorate General of Taxes. Taxable Enterpreneurs (PKP) required to make e-Invoice are Taxable Entrepreneurs (PKP) which have been stipulated by the decision of the Director General of Taxes. EInvoice Form is an electronic document Tax Invoice which is the output (output) of the application or electronic system specified and / or provided by the Directorate General of Taxes. e-Invoices shall be reported by Taxable Entrepreneurs to the Directorate General of Taxes by uploading them to the Directorate General of Taxes and obtaining persetujan from the Directorate General of Taxes. The Directorate General of Tax shall approve each eInvoice that has been uploaded as long as the serial number of the tax invoice used for the eInvoice numbering is the serial number of the tax invoice provided by the Directorate General of Taxation to the Taxable Entrepreneur who makes the e-Invoice accordingly with applicable terms.

Annual SPT Electronic is SPT Annual Income Tax delivered in the form of electronic document, either SPT Normal or SPT Correction.

SPT Masa Elektronic is SPT Period of Income Tax from SPT Value Added Tax Period submitted in electronic document form either SPT Normal or SPT Correction.

Electronic SPT Application is software that can be used to make SPT Electronic either provided by Directorate General of Taxes and service provider of SPT Elektonic.

Electronic Certificates are electronic certificates that create Electronic Signatures and identities that indicate the legal status of the parties concerned in electronic transactions issued by the Directorate General of Taxation or the providers of electronic certification.

The State Revenue Transaction Number hereinafter abbreviated as NTPN is the Receipt Transaction Receipt Number issued through the State Revenue Module.

Taxpayers may submit SPT Elektronik to KPP by:

1. Direct

2. Sent by post with proof of mail delivery

3. Sent through an expedition / courier service company with proof of mail delivery; or

4. Through certain channels established by the Director General of Taxes in accordance with the development of information technology. 


\subsection{Previous Research}

According to the previous authorization of Andik (2016) in his research / his thesis entitled "Analysis of Value Added Tax Calculation and Reporting on CV. Multi Karya Teknik (E-Invoice Based) in Sidoarjo ". Explain that to know and illustrate how the application of Value Added Tax (VAT) and its (e-invoice based) is the latest administration system. The results concluded that CV. Multi Karya Teknik in applying VAT has been in accordance with Law no. However, in the use of the e-invoice administration system to issue tax invoices as well as the calculation of VAT period still need to be increased again, because this system is online based so to revise the errors will be difficult, the improvement of employee quality is also done by $\mathrm{CV}$. Multi Karya Teknik to avoid the mistakes that cause sanctions imposed on the error.

According to previous research from Novi (2012) in research / skripsi entitled "Analysis of Value Added Tax (VAT) At CV. Sarana Teknik Kontrol Surabaya ". This study explains that in calculating Value Added Tax (VAT) can be used indirect method that is the output tax minus the income tax obtained is a tax that must be deposited into the state treasury. In recording the Value Added Tax for the purpose of making financial statements required clear information about the transactions related to Value Added Tax is the sale and purchase transactions. With the recalculation of Value Added Tax (VAT) on CV. Sarana Teknik Kontrol can be known the amount of Value Added Tax which should be the burden of this company. So the results after the recalculation of the company's profit becomes higher than the original state. That is, because the Value Added Tax (VAT) which is the burden of the company is large.

\section{RESEARCH METHODS}

In analyzing the data obtained, used descriptive data analysis method, where the information and data collected, processed, and analyzed to arrive at a conclusion that is relevant to the theory and in accordance with the applicable law namely Law No.42 of 2009 on Income Tax Value (VAT)

The type of data used in this study using qualitative data types. Qualitative is data in the form of words not in the form of numbers obtained from various techniques of data collection through interviews, document analysis, focused discussions or observations recorded in the report (Indrianto, 2009: 96).

\section{RESEARCH RESULT AND DISCUSSION 4.1 Company Profile}

PT. Berkat Rehobot is a company engaged in the transportation of Fuel Oil (BBM) for Industry, Mining and Bunker. PT. Berkat Rehobot domiciled in Manado precisely the Complex in Manado Harbor Shop No.12, Wenang Utara Village, Wenang District, Manado City, North Sulawesi Province. PT. Berkat Rehobot also has a branch office located in Bitung precisely Jl. Asabri II, No.88, Girian Permai Village, Bitung City, North Sulawesi Province. In carrying out its business and business PT. Berkat Rehobot has established cooperation with PT. Pertamina (Persero), PT. Pertamina Patra Niaga as well as various Shipping Companies to fulfill the required fuel supply (BBM). Currently PT. Berkat Rehobot has been serving the needs of consumers by using the means of land transport (Tank Car) as well as sea transport (Tanker Ship), both located in Sulawesi, Sangihe Talaud Islands to Halmahera, North Maluku.

PT. Berkat Rehobot also has several fleet support in serving the delivery of fuel to consumers, namely:

- Fleet Land:

7 Tank Car Units $\quad(8,000$ liter $)$ 
2 Tank Car Units $\quad$ (16.000 liter)

2 Tank Car Units $\quad(24,000$ liter $)$

- Sea Fleet:

Oil Tanker MT. Permata Selatan $\quad(1,000 \mathrm{KL})$

Oil Tanker MT. Keiyo $\quad(1,100 \mathrm{KL})$

Oil Tanker MT. Kencana $5 \quad$ (1,100 KL)

\subsection{Research Results}

Sales and Purchases PT. Berkat Rehobot (January 2016 - December 2016)

\begin{tabular}{|l|l|l|l|l|l|}
\hline No & $\begin{array}{c}\text { Transactions } \\
\text { (Month) }\end{array}$ & \multicolumn{1}{|c|}{ Sales } & \multicolumn{1}{|c|}{ VAT } & \multicolumn{1}{|c|}{ Purchase } & VAT \\
\hline 1 & January & 2.124 .154 .600 & 212.415 .460 & 3.197 .298 .960 & 319.729 .896 \\
\hline 2 & February & 10.363 .335 .125 & 1.036 .333 .512 & 4.922 .473 .030 & 492.247 .303 \\
\hline 3 & March & 4.060 .300 .400 & 406.030 .040 & 5.523 .876 .190 & 552.387 .613 \\
\hline 4 & April & 5.714 .400 .950 & 571.440 .093 & 4.981 .029 .100 & 498.102 .910 \\
\hline 5 & May & 2.284 .299 .300 & 228.429 .928 & 3.477 .184 .881 & 347.718 .487 \\
\hline 6 & June & 4.597 .837 .800 & 459.783 .778 & 2.075 .930 .364 & 207.593 .036 \\
\hline 7 & July & 153.120 .000 & 15.312 .000 & 2.698 .787 .364 & 269.878 .736 \\
\hline 8 & August & 2.921 .912 .800 & 292.191 .280 & 4.317 .687 .364 & 431.768 .736 \\
\hline 9 & September & 7.036 .548 .000 & 703.654 .801 & 4.073 .809 .045 & 407.380 .904 \\
\hline 10 & October & 4.167 .636 .700 & 416.763 .670 & 3.478 .826 .455 & 347.882 .645 \\
\hline 11 & November & 6.775 .260 .440 & 677.526 .045 & 3.654 .098 .100 & 365.409 .810 \\
\hline 12 & December & 6.845 .080 .925 & 684.508 .093 & 4.117 .513 .000 & 411.751 .300 \\
\hline
\end{tabular}

Source: Data Processed

Sales and Purchases PT. Berkat Rehobot (January 2017 - December 2017)

\begin{tabular}{|l|l|l|l|l|l|}
\hline No & $\begin{array}{c}\text { Transactions } \\
\text { (Month) }\end{array}$ & \multicolumn{1}{|c|}{ Sales } & \multicolumn{1}{c|}{ VAT } & Purchase & VAT \\
\hline 1 & January & 3.623 .993 .975 & 362.399 .398 & 2.270 .020 .632 & 227.002 .068 \\
\hline 2 & February & 2.398 .029 .600 & 239.802 .960 & 1.979 .110 .088 & 197.911 .013 \\
\hline 3 & March & 4.961 .221 .325 & 496.122 .133 & 4.464 .477 .183 & 446.447 .720 \\
\hline 4 & April & 4.537 .854 .175 & 453.785 .417 & 3.652 .208 .000 & 365.220 .800 \\
\hline 5 & May & 4.395 .785 .125 & 439.578 .512 & 2.902 .900 .000 & 290.290 .000 \\
\hline 6 & June & 5.602 .519 .100 & 560.251 .909 & 3.124 .467 .819 & 312.446 .781 \\
\hline 7 & July & 3.444 .284 .010 & 344.428 .401 & 3.448 .952 .000 & 344.895 .200 \\
\hline 8 & August & 7.401 .418 .000 & 740.141 .0799 & 4.612 .431 .000 & 461.243 .100 \\
\hline 9 & September & 4.018 .871 .240 & 401.887 .124 & 3.702 .120 .000 & 370.212 .000 \\
\hline 10 & October & 1.926 .896 .000 & 192.689 .600 & 4.656 .213 .600 & 465.621 .360 \\
\hline 11 & November & 5.209 .883 .330 & 520.988 .333 & 4.942 .315 .036 & 494.231 .506 \\
\hline 12 & December & 10.243 .075 .090 & 1.024 .307 .507 & 3.933 .855 .440 & 393.385 .544 \\
\hline
\end{tabular}

Source: Data Processed

\subsubsection{Recording of Value Added Tax (VAT)}

Examples of recording by a company for Value Added Tax (VAT)

\section{VAT Recording}

\section{July 2016}

Transaction Journal of Output Tax

Accounts Receivable Rp 168,432,000, -

DPP Sales

Rp 153,120,000, - 


\section{VAT Output}

Transaction Journal of Input Tax

DPP Purchase

VAT Input

Accounts Payable
Rp 15.312.000, -

Rp 2.698.787.364, -

Rp 269,878,736, -

Rp 2,968,666,100, -

More VAT Paid Journal

VAT Output

More Pay

$$
\text { VAT Input }
$$

Rp 15.312.000, -

Rp 254.566.736, -

In July 2016 VAT The smaller output is Rp 15.312.000, - while the Input VAT is Rp $269,878,736$, - so the Overpayment of VAT in July 2016 amounts to Rp 254,566,736, - then is compensated to the tax period of the following month.

\subsubsection{Calculation of Value Added Tax (VAT)}

CALCULATION VAT 2016

\begin{tabular}{|c|c|c|c|c|c|}
\hline \multirow{2}{*}{ No } & \multirow{2}{*}{$\begin{array}{c}\text { Tax Period } \\
2016\end{array}$} & \multicolumn{2}{|c|}{ VAT CONTINUED OWN } & \multirow{2}{*}{$\begin{array}{c}\text { Pay Less / More } \\
\text { Pay (Rp) }\end{array}$} & \multirow[t]{2}{*}{ KET } \\
\hline & & Output VAT & $\begin{array}{r}\text { VAT Input } \\
\end{array}$ & & \\
\hline 1 & January & 212.415 .460 & 319.729 .896 & $(107.314 .436)$ & $\begin{array}{l}\text { Compensated } \\
\text { next month }\end{array}$ \\
\hline 2 & February & 1.036 .333 .512 & $\begin{array}{l}492.247 .303+107.314 .436 \\
\text { (Compensation in January) }= \\
599.561 .739\end{array}$ & 436.771 .773 & \\
\hline 3 & March & 406.030 .040 & 552.387 .613 & $(146.357 .573)$ & $\begin{array}{l}\text { Compensated } \\
\text { next month }\end{array}$ \\
\hline 4 & April & 571.440 .093 & $\begin{array}{l}498.102 .910+146.357 .573 \\
\text { (Compensation in March ) }= \\
644.460 .483\end{array}$ & $(73.020 .390)$ & $\begin{array}{l}\text { Compensated } \\
\text { next month }\end{array}$ \\
\hline 5 & May & 228.429 .928 & $\begin{array}{l}347.718 .487+73.020 .390 \\
\text { (Compensation in April ) }= \\
420.738 .877\end{array}$ & $(192.308 .949)$ & $\begin{array}{l}\text { Compensated } \\
\text { next month }\end{array}$ \\
\hline 6 & June & 459.783 .778 & $\begin{array}{l}207.593 .036+192.308 .949 \\
\text { (Compensation in May) }= \\
399.901 .985\end{array}$ & 59.881 .793 & \\
\hline 7 & July & 15.312 .000 & 269.878 .736 & $(254.566 .736)$ & $\begin{array}{l}\text { Compensated } \\
\text { next month }\end{array}$ \\
\hline 8 & August & 292.191 .280 & $\begin{array}{l}431.768 .736+254.566 .736 \\
\text { (Compensation in July) }= \\
686.335 .472\end{array}$ & $(394.144 .192)$ & $\begin{array}{l}\text { Compensated } \\
\text { next month }\end{array}$ \\
\hline 9 & September & 703.654 .801 & $\begin{array}{l}407.380 .904+394.144 .192 \\
\text { (Compensation in August) }= \\
801.525 .096\end{array}$ & $(97.870 .295)$ & $\begin{array}{l}\text { Compensated } \\
\text { next month }\end{array}$ \\
\hline 10 & October & 416.763 .670 & $\begin{array}{l}347.882 .645+97.870 .295 \\
\text { (Compensation in September) }= \\
445.752 .940\end{array}$ & $(28.989 .270)$ & $\begin{array}{l}\text { Compensated } \\
\text { next month }\end{array}$ \\
\hline 11 & November & 677.526 .045 & $\begin{array}{l}365.409 .810+28.989 .270 \\
\text { (Compensation in October) }= \\
394.399 .080\end{array}$ & 283.126 .965 & \\
\hline 12 & December & 684.508 .093 & 411.751 .300 & 272.756 .793 & \\
\hline
\end{tabular}

Source: Data Processed 


\begin{tabular}{|c|c|c|c|c|c|}
\hline \multicolumn{6}{|c|}{ CALCULATION VAT 2017} \\
\hline \multirow{2}{*}{ No } & \multirow{2}{*}{$\begin{array}{c}\text { Tax Period } \\
2017\end{array}$} & \multicolumn{2}{|c|}{$\begin{array}{l}\text { VAT CONTINUED OWN } \\
\end{array}$} & \multirow{2}{*}{$\begin{array}{c}\text { Pay Less / More } \\
\text { Pay (Rp) }\end{array}$} & \multirow[t]{2}{*}{ KET } \\
\hline & & Output VAT & VAT Input & & \\
\hline 1 & January & 362.399 .398 & 227.002 .068 & 135.397 .330 & \\
\hline 2 & February & 239.802 .960 & 197.911 .013 & 41.891 .947 & \\
\hline \multirow[t]{2}{*}{3} & March & 496.122 .133 & 446.447 .720 & 49.674 .413 & \\
\hline & $\begin{array}{l}\text { Rectification } \\
1\end{array}$ & 496.122 .133 & 562.670 .106 & $(66.547 .973)$ & $\begin{array}{l}\text { Compensated } \\
\text { next month }\end{array}$ \\
\hline \multirow[t]{2}{*}{4} & April & 453.785 .417 & $\begin{array}{l}365.220 .800+6 \\
\text { (Compensation in March) }= \\
431.768 .773\end{array}$ & 22.016 .644 & \\
\hline & $\begin{array}{l}\text { Rectification } \\
1\end{array}$ & 453.785 .417 & 544.720 .990 & $(90.935 .573)$ & $\begin{array}{l}\text { Compensated } \\
\text { next month }\end{array}$ \\
\hline 5 & May & 439.578 .512 & $\begin{array}{l}290.290 .000+ \\
\text { (Compensation in April) }= \\
381.225 .573\end{array}$ & 58.352 .939 & \\
\hline 6 & June & 560.251 .909 & 312.446 .781 & 247.805 .128 & \\
\hline 7 & July & 344.428 .401 & 344.895 .200 & $(466.799)$ & $\begin{array}{l}\text { Compensated } \\
\text { next month }\end{array}$ \\
\hline 8 & August & 740.141 .799 & $\begin{array}{llr}461.243 .100 & + & 466.799 \\
\text { (Compensation } & \text { in } & \text { July) } \\
461.709 .899 & & \end{array}$ & 278.431 .900 & \\
\hline 9 & September & 401.887 .124 & 370.212 .000 & 31.675 .124 & \\
\hline 10 & October & 192.689 .600 & 465.621 .360 & $(272.931 .760)$ & $\begin{array}{l}\text { Compensated } \\
\text { next month }\end{array}$ \\
\hline 11 & November & 520.988 .333 & $\begin{array}{l}494.231 .506+272.931 .760 \\
\text { (Compensation in October) }= \\
767.163 .266\end{array}$ & $(246.174 .933)$ & $\begin{array}{l}\text { Compensated } \\
\text { next month }\end{array}$ \\
\hline 12 & December & 1.024 .307 .507 & $\begin{array}{l}393.385 .544+246.174 .933 \\
\text { (Compensation in November) } \\
=639.560 .477\end{array}$ & 384.747 .030 & \\
\hline
\end{tabular}

Source: Data Processed

\subsubsection{Value Added Tax Reporting (VAT)}

\section{Start Page e-Faktur}

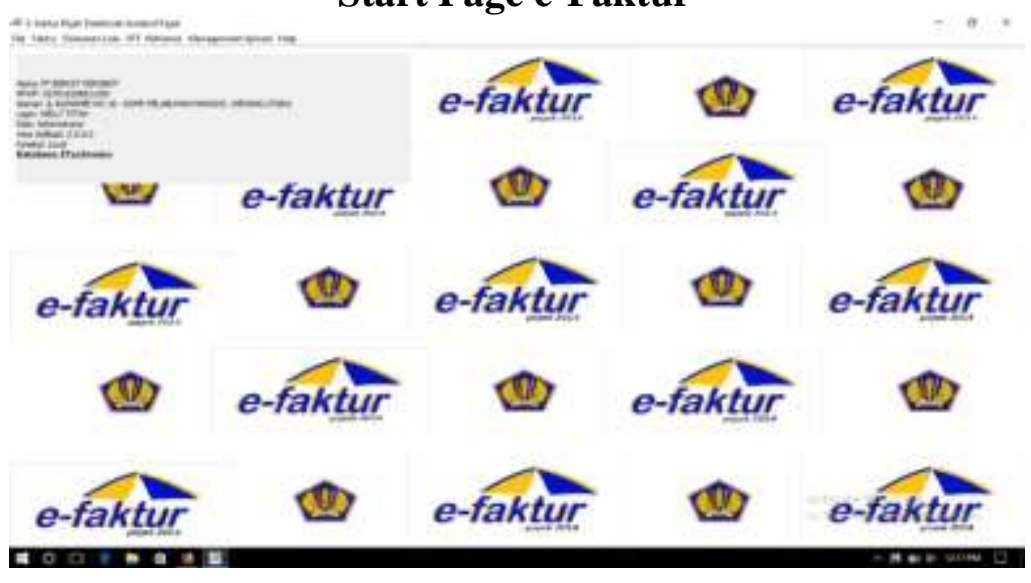

The picture above is the starting page of the Application of Value Added Tax (VAT). 


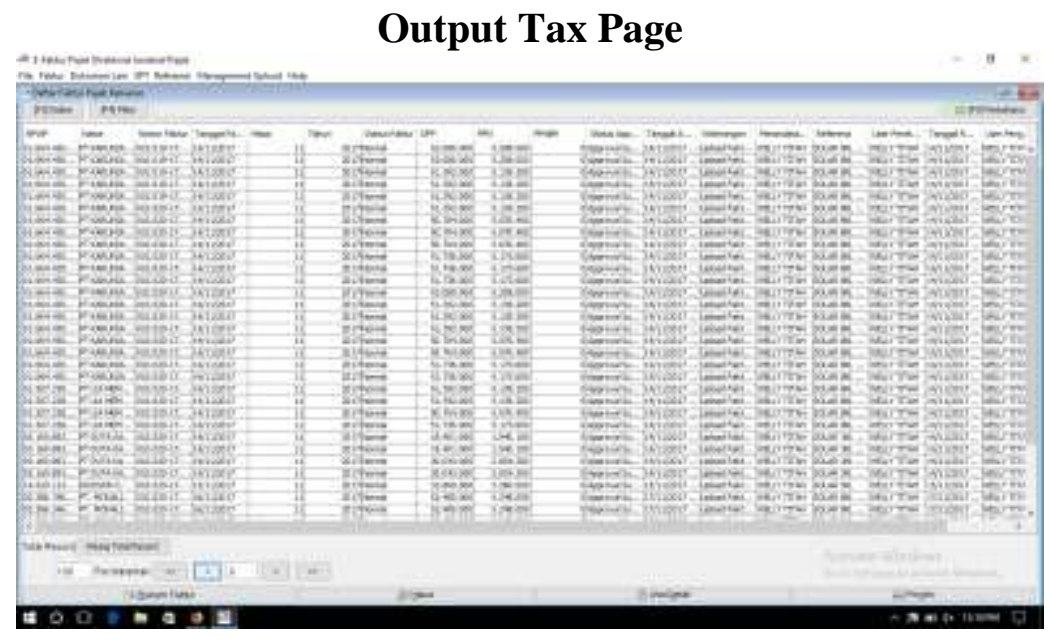

The picture above is the Recap of Output Tax in the Application of Value Added Tax (VAT)

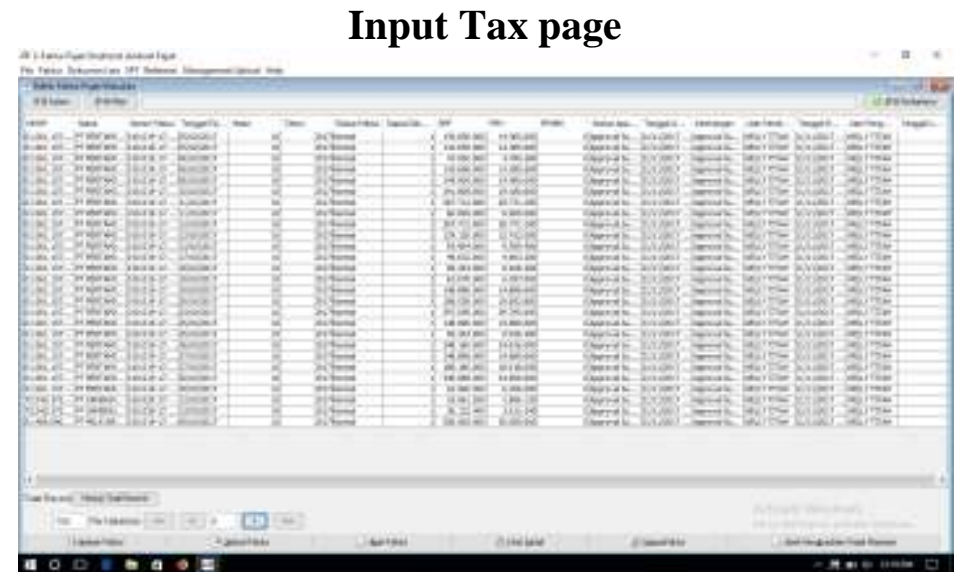

The picture above is the Input Tax Recap page from the Application of Value Added Tax (VAT)

Page Creating CSV and Printing

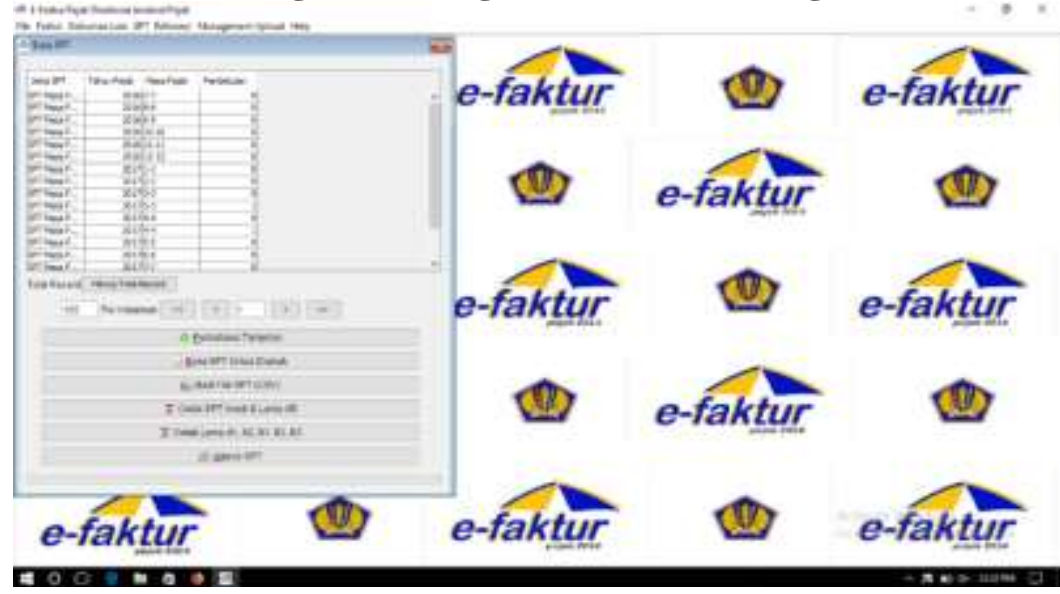


The picture above is a page for creating a CSV and printing the main SPT page, Appendix AB, Appendix A1 and Appendix B1 in the e-Faktur Application to be reported at the Primary Tax Office of Manado.

The Date of Deposit and Value Added Tax (VAT) Year 2016

\begin{tabular}{|c|c|c|c|}
\hline Tax period & Deposit Date & Reporting Date & Appropriate or Inappropriate \\
\hline $\begin{array}{l}\text { January : } \\
\text { Normal } \\
\text { Rectification 1 }\end{array}$ & $\begin{array}{l}- \\
-\end{array}$ & $\begin{array}{l}29-02-2016 \\
31-05-2016\end{array}$ & Appropriate \\
\hline $\begin{array}{l}\text { February : } \\
\text { Normal } \\
\text { Rectification } 1\end{array}$ & $\begin{array}{l}- \\
19-07-2016\end{array}$ & $\begin{array}{l}31-03-2016 \\
20-07-2016 \\
\end{array}$ & Appropriate \\
\hline $\begin{array}{l}\text { March : } \\
\text { Normal } \\
\text { Rectification } 1\end{array}$ & $\begin{array}{l}- \\
-\end{array}$ & $\begin{array}{l}29-04-2016 \\
20-07-2016 \\
\end{array}$ & Appropriate \\
\hline $\begin{array}{l}\text { April : } \\
\text { Normal } \\
\text { Rectification } 1\end{array}$ & $\begin{array}{l}- \\
-\end{array}$ & $\begin{array}{l}31-05-2016 \\
20-07-2016\end{array}$ & Appropriate \\
\hline $\begin{array}{l}\text { May: } \\
\text { Normal } \\
\text { Rectification } 1\end{array}$ & $\begin{array}{l}- \\
-\end{array}$ & $\begin{array}{l}30-06-2016 \\
20-07-2016 \\
\end{array}$ & Appropriate \\
\hline $\begin{array}{l}\text { June : } \\
\text { Normal } \\
\text { Rectification 1 }\end{array}$ & $\begin{array}{l}- \\
12-08-2016\end{array}$ & $\begin{array}{l}29-07-2016 \\
12-08-2016\end{array}$ & Appropriate \\
\hline July & - & $31-10-2016$ & Inappropriate \\
\hline August & - & $31-10-2016$ & Inappropriate \\
\hline September & - & $31-10-2016$ & Appropriate \\
\hline October & - & $30-11-2016$ & Appropriate \\
\hline November & $05-01-2017$ & $09-01-2017$ & Inappropriate \\
\hline December & $31-01-2017$ & $31-01-2017$ & Appropriate \\
\hline
\end{tabular}

Source: Data Processed

The Date of Deposit and Value Added Tax (VAT) Year 2017

\begin{tabular}{|l|l|l|l|}
\hline \multicolumn{1}{|c|}{ Tax period } & \multicolumn{1}{|c|}{ Deposit Date } & Reporting Date & Appropriate or Inappropriate \\
\hline January & $27-02-2017$ & $28-02-2017$ & Appropriate \\
\hline February & $29-03-2017$ & $30-03-2017$ & Appropriate \\
\hline $\begin{array}{l}\text { March : } \\
\text { Normal } \\
\text { Rectification 1 }\end{array}$ & $27-04-2017$ & $\begin{array}{l}28-04-2017 \\
22-06-2017\end{array}$ & Appropriate \\
\hline $\begin{array}{l}\text { April : } \\
\text { Normal } \\
\text { Rectification 1 }\end{array}$ & - & & \\
\hline May & $21-06-2017$ & $22-06-2017$ & Appropriate \\
\hline June & $31-07-2017$ & $31-07-2017$ & Appropriate \\
\hline July & - & $31-08-2017$ & Appropriate \\
\hline August & $28-09-2017$ & $29-09-2017$ & Appropriate \\
\hline September & $30-10-2017$ & $31-10-2017$ & Appropriate \\
\hline October & - & $29-11-2017$ & Appropriate \\
\hline November & - & $20-12-2017$ & Appropriate \\
\hline December & $30-01-2018$ & $31-01-2018$ & Appropriate \\
\hline
\end{tabular}

Source: Data Processed

\subsection{Discussion}

In the application of Value Added Tax (VAT) of Taxable Entrepreneur (PKP) PT. Berkat Rehobot already using computerized system. But it is often still a mistake because it does not have a program that supports it well. 
PT. Berkat Rehobot doing sales and purchases of Fuel (BBM). When a company purchases materials that are Taxable Goods (PPA) on a Taxable Enterpreneur (PKP) the company will be levied with Value Added Tax (VAT) which will be the Input Tax for the company, and the company will get tax invoice from the purchase of material as evidence of levies Value Added Tax (VAT). Also when a company makes a sale on a Taxable Entrepreneur (PKP) the company will issue a tax invoice from the sale so that the company gets the output tax.

In the taxation system there are two methods of accounting recording that are recognized by the Directorate General of Taxes, namely cash base method (cash basis) and accrual basis method (accrual basic). Of these two methods have one common goal that is, intended that from the bookkeeping can be calculated how much tax payable.

In the calculation and reporting of Value Added Tax (VAT) of PT. Berkat Rehobot has used the e-Faktur Application as stipulated in the Regulation of the Director General of Tax No. PER-16 / PJ / 2014 so that the calculation and reporting there is easier and accurate. Electronic tax invoices, hereinafter referred to as e-Faktur are tax invoices made through electronic applications or systems specified and / or provided by the Directorate General of Taxes. e-Faktur Required reported by PT. Berkat Rehobot to the Directorate General of Taxes by uploading to the Directorate General of Taxes and obtaining approval from the Directorate General of Taxes. The Directorate General of Tax shall approve each e-Faktur that has been uploaded as long as the Serial Number of Tax Invoice used for the numbering of the e-Faktur shall be the Serial Number of Tax Invoice granted by the Directorate General of Taxation to the Taxable Entrepreneur who makes the e-Faktur accordingly with applicable terms.

\section{RESULTS AND DISCUSSIONS \\ 5.1 Results}

Based on research conducted at PT. Berkat Rehobot conclusions that can be drawn among others. Research conducted on the recording, calculation and reporting of Value Added Tax (VAT) at PT. Berkat Rehobot it can be concluded that this company has made accounting of Value Added Tax (VAT) in accordance with Law Number 42 Year 2009 is using an accrual based system that has been in accordance with the rules of Accounting recording generally accepted.

As for the calculation of Value Added Tax (VAT) at PT. Berkat Rehobot as a whole has been in accordance with current regulations because PT. Berkat Rehobot has used the eFaktur application so that the calculation using the existing app so that the lack of errors that occur.

For Value Added Tax (VAT) at PT. Berkat Rehobot has been in accordance with the current rules as it is the same as the calculation, the reporting of Value Added Tax (VAT) also uses e-Faktur application that is after input data Output Tax and Input Tax in e-Faktur application can be automatically SPT The time is finished so it can be reported to Tax Office Pratama Manado by using hardcopy and softcopy so that the lack of error happened. If there is a lack of delays or correction in reporting due to delays in the delivery of existing Input Tax Invoice. However, the overall calculation and reporting has been in accordance with the Director General of Tax Regulation No. PER-16 / PJ / 2014.

\subsection{Discussions}

From Conclusion Research conducted at PT. Berkat Rehobot the writer can give suggestion: 
1. Records that exist in the company should be more attention in accordance with existing regulations such as Law No. 42 of 2009 and PSAK in order not to experience fatal mistakes that can harm the company.

2. Companies should also pay more attention to the existing Tax Regulations because Taxation Regulations are often changed so that more attention should be paid by the company so as not to experience errors in the recording, calculation and reporting of PT. Berkat Rehobot.

3. The Company must also improve the Human Resources (HR) in understanding eInvoice in calculating and reporting Value Added Tax (VAT) every month. Because the existing e-Faktur application is often rapidly changing in its application according to the Directorate General of Tax Regulation.

\section{REFERENCES}

Darmayanti, Novi., 2012, "Analisis Perhitungan Pajak Pertambahan Nilai (PPN) Pada CV. Sarana Teknik Kontrol Surabaya". Jurnal Manajemen dan Akuntansi, Vol. 1, No. 3 December 2012, Page 29-44.

Firmansyah, Andik., Hidayati, Kusni., Pudjowati, Juliani., 2016, "Analisis Penerapan Perhitungan Pajak Pertambahan Nilai Dan Pelaporannya Pada CV. Multi Karya Teknik (Berbasis E-Faktur) Di Sidoarjo" Accounting Study Program Faculty of Economics University Bhayangkara Surabaya.

Mardiasmo. 2009. Perpajakan Edisi Revisi 2009. Penerbit Andi. Yogyakarta.

Materi Pengertian Akuntansi Keuangan Fungsi dan Standarisasi. https://ruangakuntansi.wordpress.com/2017/03/02/pengertian-akuntansikeuangan-fungsistndarnya.html. Accessed on Oktober, 12, 2017.

Muljono. 2009. Akuntansi Pajak Lanjutan. Penerbit Andi. Yogyakarta.

Pengertian Akuntansi Definisi Arti dan Fungsi Akuntansi. https://www.contohsurat.co.id/2016/09/akuntansi.html. Accessed on Oktober, 12, 2017.

Pengertian Akuntansi Secara Lengkap. https://jowonews.com/2017/09/05/pengertianakuntansi-secara-lengkap.html. Accessed on Oktober, 12, 2017.

Peraturan Jenderal Pajak Nomor Per-16/PJ/2014 Tentang Tata Cara Pembuatan dan Pelaporan Faktur Pajak Berbentuk Elektronik. Accessed on Oktober, 12, 2017. 